OPEN ACCESS

Edited by:

Filip Krag Knop,

Gentofte Hospital, Denmark

Reviewed by:

Nicolai Jacob Wewer Albrechtsen, Rigshospitalet, Denmark

Chinmay Marathe,

University of Adelaide, Australia

*Correspondence:

Bo Ahrén

Bo.Ahren@med.lu.se

Specialty section:

This article was submitted to

Gut Endocrinology,

a section of the journal

Frontiers in Endocrinology

Received: 08 February 2021 Accepted: 21 April 2021

Published: 27 May 2021

Citation:

Ahrén B, Yamada $Y$ and Seino $Y$ (2021) The Insulin Response to Oral Glucose in GIP and GLP-1 Receptor

Knockout Mice: Review of the

Literature and Stepwise Glucose Dose Response Studies in Female Mice.

Front. Endocrinol. 12:665537. doi: 10.3389/fendo.2021.665537

\section{The Insulin Response to Oral Glucose in GIP and GLP-1 Receptor Knockout Mice: Review of the Literature and Stepwise Glucose Dose Response Studies in Female Mice}

\author{
Bo Ahrén ${ }^{1 *}$, Yuichiro Yamada ${ }^{2}$ and Yutaka Seino ${ }^{3}$ \\ ${ }^{1}$ Department of Clinical Sciences Lund, Lund University, Lund, Sweden, ${ }^{2}$ Department of Endocrinology, Diabetes and Geriatric \\ Medicine, Graduate School of Medicine, Akita University, Akita, Japan, ${ }^{3}$ Kansai Electric Power Hospital, Osaka, Japan
}

A key factor for the insulin response to oral glucose is the pro-glucagon derived incretin hormone glucagon-like peptide-1 (GLP-1), together with the companion incretin hormone, glucose-dependent insulinotropic polypeptide (GIP). Studies in GIP and GLP-1 receptor knockout (KO) mice have been undertaken in several studies to examine this role of the incretin hormones. In the present study, we reviewed the literature on glucose and insulin responses to oral glucose in these mice. We found six publications with such studies reporting results of thirteen separate study arms. The results were not straightforward, since glucose intolerance in GIP or GLP-1 receptor KO mice were reported only in eight of the arms, whereas normal glucose tolerance was reported in five arms. A general potential weakness of the published study is that each of them have examined effects of only one single dose of glucose. In a previous study in mice with genetic deletion of both GLP-1 and GIP receptors we showed that these mice have impaired insulin response to oral glucose after large but not small glucose loads, suggesting that the relevance of the incretin hormones may be dependent on the glucose load. To further test this hypothesis, we have now performed a stepwise glucose administration through a gastric tube (from zero to $125 \mathrm{mg}$ ) in model experiments in anesthetized female wildtype, GLP-1 receptor KO and GIP receptor KO mice. We show that GIP receptor $\mathrm{KO}$ mice exhibit glucose intolerance in the presence of impaired insulin response after 100 and $125 \mathrm{mg}$ glucose, but not after lower doses of glucose. In contrast, GLP-1 receptor KO mice have normal glucose tolerance after all glucose loads, in the presence of a compensatory increase in the insulin response. Therefore, based on these results and the literature survey, we suggest that GIP and GLP-1 receptor $\mathrm{KO}$ mice retain normal glucose tolerance after oral glucose, except after large glucose loads in GIP receptor KO mice, and we also show an adaptive mechanism in GLP-1 receptor $\mathrm{KO}$ mice, which needs to be further examined.

Keywords: GLP-1, GIP, knockout mice, glucose tolerance, insulin 


\section{INTRODUCTION}

Following its first conductancy in 1917, the oral glucose tolerance test (OGTT) has been a standard technique in experimental and clinical medicine and has particularly since 1980 been a key tool for diagnosis and screening of impaired glucose tolerance and type 2 diabetes (1). A key factor for the glucose tolerance after oral glucose is the augmentation of the insulin response by the incretin hormones, glucose-dependent insulinotropic polypeptide (GIP) and glucagon-like peptide-1 (GLP-1) (2-4). In fact, GIP and GLP-1 have been suggested to be responsible for approximately $60-70 \%$ of the insulin response after oral glucose, as judged from studies evaluating the difference in insulinemia after intravenous versus oral glucose administration at matched glucose levels both in humans (5) and animals (6).

Mice with genetic deletion of GIP receptors or GLP-1 receptors have been used to examined the impact on the two incretin hormones (7). To study the reported impact on glucose and insulin responses to oral glucose in these mice, we reviewed the literature in which studies on oral glucose challenges in GIP receptor $\mathrm{KO}$ or GLP-1 receptor $\mathrm{KO}$ mice have been performed. We found such studies reported in several studies (8-14) but that the clear role of the incretin hormones to maintain normal glucose and insulin responses to oral glucose was not entirely consistent, mainly because the responses were in general studied after a single dose of glucose administration. We have, furthermore, previously performed a stepwise oral glucose administration in mice with double genetic deletion of both GIP and GLP-1 receptors (DIRKO mice) (15). That study showed that these mice have glucose intolerance with impaired increase in insulin levels only after a large glucose load (75 and $100 \mathrm{mg}$ ), but not after smaller glucose loads (25 and 50mg). A glucose dependent nature of the impact of genetic deletion of GIP and GLP-1 receptors on glucose and insulin responses to oral glucose may therefore exist, which may explain the partial inconsistency in the literature. To test this hypothesis we have, in the present study, therefore undertaken a study on the glucose and insulin responses to stepwise oral glucose administration over a wide range in GIP receptor $\mathrm{KO}$ and GLP-1 receptor $\mathrm{KO}$ mice.

\section{METHODS}

\section{Literature Survey}

Key words for GIP receptor KO mice and GLP-1 receptor KO mice combined with oral glucose, glucose tolerance and insulin secretion were introduced in the PubMed data base. The found studies were read in detail in regard to methodology (gender and age of mice, length of fasting and oral glucose load, number of animals in each study arm, and results on glycemia and insulinemia).

\section{Animals}

The generation of GLP-1 receptor $\mathrm{KO}$ mice and GIP receptor $\mathrm{KO}$ mice has been described previously (14). Briefly, mice on a
C57BL6J background being heterozygous for the deletion of both the Glp1r and Gipr genes were generated from double homozygous deletion mutant mice by rederivation at Taconic Europe (Silkeborg, Denmark). Heterozygotes were mated to yield GLP-1 receptor KO mice, GIP receptor KO mice, and wildtype mice. The resulting offspring was used to establish breeding pairs, whose offspring was used in the experiments. All experiments were undertaken in female mice of 4-6 months of age. The animals were maintained in a temperature-controlled room $\left(22^{\circ} \mathrm{C}\right)$ on a $12: 12 \mathrm{~h}$ light-dark cycle (light on at 7:00 AM). Mice were fed a standard pellet diet (total energy $14.1 \mathrm{MJ} / \mathrm{kg}$ with $14 \%$ from fat, $60 \%$ from carbohydrate and $26 \%$ from protein; SAFE, Augy, France) and tap water ad libitum. During experimental days, food was removed from the cages at 7:30 $\mathrm{AM}$ and the actual experiments started at 12:30, i.e., during the light cycle. We used female mice only to avoid the stress of single housing, which is used in male mice, and to be in line with the previous study in GIP receptor KO and GLP-1 receptor KO mice (16). We used the mice randomly during the estrous cycle. The study was approved by the Lund/Malmö Animal Ethics Committee (Approval No. 5.8.18-06417/2020) and performed according to Good Laboratory Practice.

\section{Animal Disposition}

A total of 238 animals were allocated for experimental procedure (98 wildtype mice, 68 GIP receptor KO mice and 72 GLP-1 receptor $\mathrm{KO}$ mice). Studies were undertaken in batches of 6-8 mice on each experimental day by one experienced technician. In all individual experiments, animals from all individual subgroups were involved to avoid bias in different results on different days. Table 1 shows the detailed number of animals in each of the study groups. All individual results from the completer population were included in the final analysis and statistics.

\section{Experiments}

After a 5-h fast, mice were anesthetized with a fixed dose combination of fentanyl (0.02 mg/mouse)-fluanisone $(0.5 \mathrm{mg} /$ mouse) (Hypnorm ${ }^{\mathrm{R}}$; Vetpharma, Leeds, UK) and midozalam (0.125 mg/mouse; Roche, Basel, Switzerland) and given glucose (25-125 mg per mouse, dissolved in saline) or saline alone (i.e., 0 $\mathrm{mg}$ glucose) in the stomach through a gastric tube (outer diameter $1.2 \mathrm{~mm}$ ). Whole blood was sampled in heparinized pipettes from the intraorbital retrobulbar sinus plexus $(40 \mu \mathrm{l})$ at $0,15,30$ and $60 \mathrm{~min}$. Plasma was separated by centrifugation and stored at $-20^{\circ} \mathrm{C}$ until analysis for insulin.

TABLE 1 | Number of animals in each of the study groups in this project.

\begin{tabular}{lccc}
\hline $\begin{array}{l}\text { Glucose dose } \\
\text { (mg/mouse) }\end{array}$ & $\begin{array}{c}\text { Wildtype } \\
\text { mice }\end{array}$ & $\begin{array}{c}\text { GIP receptor KO } \\
\text { mice }\end{array}$ & $\begin{array}{c}\text { GLP-1 receptor KO } \\
\text { mice }\end{array}$ \\
\hline 0 & 6 & 8 & 6 \\
25 & 11 & 11 & 10 \\
50 & 12 & 12 & 10 \\
75 & 12 & 9 & 9 \\
100 & 34 & 20 & 27 \\
125 & 24 & 8 & 16
\end{tabular}




\section{Assays}

Glucose was detected with the glucose oxidase method using Accu Chek Aviva (Hoffman-La Roche, Basel, Switzerland). Insulin was determined by ELISA (Mercodia, Uppsala, Sweden). The intra-assay coefficient of variation (CV) of the method is $4 \%$ at both low and high levels, and the interassay CV is $5 \%$ at both low and high levels. The lower limit of quantification of the assay is $6 \mathrm{pmol} / \mathrm{l}$.

\section{Data Analysis}

Data are presented as means \pm SEM. Areas under the curves (total AUCs) were calculated with the trapezoid rule using glucose and insulin levels throughout the 60 min study period. The relative increase in $\mathrm{AUC}_{\text {insulin }}$ by increasing the glucose load was estimated by calculating the ratio between $\mathrm{AUC}_{\text {insulin }}$ at each of the glucose loads divided by $\mathrm{AUC}_{\text {insulin }}$ after zero glucose. The beta cell response was estimated as $\mathrm{AUC}_{\text {insulin }}$ divided by AUC $_{\text {glucose }}$ Fasting insulin sensitivity was determined by the HOMA-R analyses (baseline glucose in $\mathrm{mmol} / \mathrm{l}$ times baseline insulin in $\mathrm{mU} / \mathrm{l}$ divided by 22.5) (17).

\section{Statistical Analysis}

Differences between experimental groups were determined using a two-way analysis of variance (ANOVA) followed by a Sidak's multiple comparisons test. Baseline insulin levels were applied to the Kolmogorov-Smirnov test for test of normality and results showed that significance for non-normality was not reached (in wildtype mice $\mathrm{P}=0.068$, in GIP receptor $\mathrm{KO}$ mice $\mathrm{P}=0.103$ and in GLP-1 receptor KO mice $\mathrm{P}=0.094$ ). For all analyses, statistical significance was defined as $P<0.05$ and data reported as means \pm SEM. Analyses were carried out using SPSS, v. 27.

\section{RESULTS}

\section{Review of the Literature}

A total of six publications were found in the PubMed data base, in which studies on glucose and insulin levels after oral glucose challenges in GIP receptor KO mice and/or in GLP-1 receptor $\mathrm{KO}$ mice were reported $(8,10-14)$. By dividing the studies into different study arms depending on gender, GIP receptor $\mathrm{KO}$ and GLP-1 receptor KO animals, a total of thirteen different study arms were reported in these six publications (Table 2). Six studies used both female and male mice, whereas two studies used only male mice. The age of the mice was in general 3-4 months. All studies used long fasting period ( $>16 \mathrm{hrs}$ ) and the number of animals in each arm did in most studies exceed six, but also low numbers of only four animals were reported in some study arms. All studies examined only a single amount of glucose load, which varied between 1 and $3 \mathrm{mg} / \mathrm{g}$. All studies measured glucose levels at several time points after glucose administration and most of them also determined the area under the glucose curve as a measure. In contrast, insulin levels were reported at several time points after glucose challenge in only one study, whereas insulin levels were usually reported at a single time point after glucose.
Result showed significantly higher glucose levels after oral glucose in GIP or GLP-1 receptor $\mathrm{KO}$ arms compared to wildtype mice (i.e., glucose intolerance) in eight of the study arms (62\%) but no difference between $\mathrm{KO}$ mice and wildtype mice in five study armss (38\%). Of the seven study arms with male mice, four had glucose intolerance (57\%) and three no difference (43\%), whereas of the six study arms with female mice, four had glucose intolerance (67\%) and two no difference (33\%). In five study arms, a high glucose loads of 2 or $3 \mathrm{mg} / \mathrm{g}$ was given and in these studies, four groups with GIP or GLP-1 receptor KO mice had glucose intolerance whereas one arm had no difference in glucose, i.e., $80 \%$ of the studies showed glucose intolerance. In contrast, in the studies using a lower glucose load of 1 or $1.5 \mathrm{mg} / \mathrm{g}$, four out of eight study arms (i.e., 50\%) showed glucose intolerance in GIP or GLP-1 receptor $\mathrm{KO}$ mice. In regard to insulinemia, lower insulin response to oral glucose in GIP or GLP-1 receptor $\mathrm{KO}$ mice compared to wildtype mice were reported in some but not in all studies. Therefore, the compiled results are not entirely consistent although approximately two third of the arms show glucose intolerance or a low insulin response to oral glucose in GIP or GLP-1 receptor KO mice; gender does not seem to explain this difference but there is a trend for a stronger phenotype after high glucose load than after low glucose load.

\section{Glucose and Insulin Responses to Stepwise Oral Glucose Administration}

The glucose and insulin levels were examined before and at 15, 30 and $60 \mathrm{~min}$ after the oral administration of glucose in the range of 0 to $125 \mathrm{mg}$ in wildtype mice and in GIP and GLP-1 receptor KO mice. Table 1 shows the number of animals in each of the study groups, and Table $\mathbf{3}$ shows baseline levels in all mice in the three mice strains. It is seen that GLP-1 receptor KO mice had higher fasting glucose than wildtype and GIP receptor KO mice. Insulin levels were not significantly different between the wildtype and the $\mathrm{KO}$ mice, although there was a trend of higher baseline insulin levels in GIP receptor $\mathrm{KO}$ mice than in wildtype mice $(\mathrm{P}=0.06)$. Fasting insulin sensitivity, as estimated by HOMA-R, was significantly lower in GIP and GLP-1 receptor $\mathrm{KO}$ mice than in wildtype mice.

Figure 1 shows glucose and insulin levels in all individual groups. After saline alone (i.e., $0 \mathrm{mg}$ glucose), glucose and insulin levels were stable throughout the 60 min study period with no significant difference between the time points in any of the groups. Glucose levels remained higher from baseline throughout the $60 \mathrm{~min}$ period in GLP-1 receptor $\mathrm{KO}$ mice comparesd to wildtype mice. After oral administraton of 25 mg glucose, there were no significant changes in glucose and insulin levels compared to fasting levels in any of the three groups. After administration of glucose at 50, 75, 100 and 125 $\mathrm{mg}$, glucose and insulin levels rose in all three groups with peaks being observed after $30 \mathrm{~min}$.

Figure 2 shows total $\mathrm{AUC}_{\text {glucose }}$ and total $\mathrm{AUC}_{\text {insulin }}$ during the 60 min test after each of the glucose doses in the three groups of mice.). In wildtype mice, $\mathrm{AUC}_{\text {glucose }}$ increased by increasing the glucose load up to $75 \mathrm{mg}$, whereas at higher glucose levels, 
TABLE 2 | Studies reporting glucose and insulin responses to oral glucose in homozygous GIP or GLP-1 receptor KO mice compared with their wildtype counterparts.

\begin{tabular}{|c|c|c|c|c|c|c|c|}
\hline Reference & Experimental groups & Number of animals & Age & $\begin{array}{l}\text { Length of } \\
\text { fasting (hrs) }\end{array}$ & $\begin{array}{l}\text { Glucose dose } \\
\text { (mg/g) }\end{array}$ & $\begin{array}{l}\text { Change in glycemia } \\
\text { versus wildtype mice }\end{array}$ & $\begin{array}{l}\text { Change in insulinemia } \\
\text { versus wildtype mice }\end{array}$ \\
\hline \multicolumn{8}{|c|}{ GIP receptor KO studies } \\
\hline Miyawaki et al. (11) & Male GIP receptor KO & 6 & 8-12 weeks & 16 & 2 & 20 and 30 min $_{\text {glucose }} \uparrow$ & 15 and 30 min $_{\text {insulin }} \downarrow$ \\
\hline Pamir et al. (12) & $\begin{array}{l}\text { Male GIP receptor KO } \\
\text { Male wildtype }\end{array}$ & $\begin{array}{c}4 \\
11 \\
7\end{array}$ & 9-14 weeks & 16 & 1 & 15 and $30 \min _{\text {glucose }} \uparrow \approx 18 \%$ & 20 min $_{\text {insulin }} \downarrow \approx 45 \%$ \\
\hline \multirow[t]{2}{*}{ Preitner et al. (13) } & $\begin{array}{l}\text { Female GIP receptor KO } \\
\text { Female wildtype }\end{array}$ & $\begin{array}{c}9 \\
11\end{array}$ & 3-4 months & 16 & 3 & AUC glucose $\uparrow \approx 50 \%$ & 15 min $_{\text {insulin }} \downarrow \approx 30 \%$ \\
\hline & $\begin{array}{l}\text { Male GIP receptor KO } \\
\text { Male wildtype }\end{array}$ & $\begin{array}{l}(12-19)^{\star} \\
(12-19)^{*}\end{array}$ & 3-4 months & 16 & 3 & AUC glucose $\uparrow \approx 30 \%$ & 15 min $_{\text {insulin }} \downarrow \approx 50 \%$ \\
\hline \multirow[t]{2}{*}{ Hansotia et al. (14) } & $\begin{array}{l}\text { Female GIP receptor KO } \\
\text { Female wildtype }\end{array}$ & $\begin{array}{l}(4-14)^{*} \\
(4-14)^{*}\end{array}$ & 9-15 weeks & $16-18$ & 1.5 & AUC $_{\text {glucose }} \leftrightarrow$ & Not determined \\
\hline & $\begin{array}{l}\text { Male GIP receptor KO } \\
\text { Male wildtype }\end{array}$ & $\begin{array}{c}(13-28)^{\star} \\
(4-14)^{\star}\end{array}$ & 9-15 weeks & $16-18$ & 1.5 & $\mathrm{AUC}_{\text {glucose }} \leftrightarrow$ & 10 min $_{\text {insulin }} \leftrightarrow$ \\
\hline \multicolumn{8}{|c|}{ GLP-1 receptor KO studies } \\
\hline \multirow[t]{2}{*}{ Scrocchi et al. (8) } & $\begin{array}{l}\text { Female GLP-1 receptor KO } \\
\text { Female wildtype }\end{array}$ & $(n=10)^{\star}$ & 6-8 weeks & 18 & 1.5 & 20,30 and 90 min $_{\text {glucose }} \uparrow$ & Not determined \\
\hline & $\begin{array}{l}\text { Male GLP-1 receptor KO } \\
\text { Male wildtype }\end{array}$ & $(n=7)^{\star}$ & 6-8 weeks & 18 & 1.5 & All time points glucose $\uparrow$ & 30 min $_{\text {insulin }} \downarrow \approx 40 \%$ \\
\hline Scrocchi et al. (9) & $\begin{array}{l}\text { Male GLP-1 receptor KO } \\
\text { Male wildtype }\end{array}$ & $\begin{array}{l}n=5 \\
n=5\end{array}$ & 3 months & $14-16$ & 1.5 & Not shown & 30 min $_{\text {insulin }} \downarrow \approx 50 \%$ \\
\hline Pederson et al. (10) & $\begin{array}{l}\text { Female and male GLP-1R KO } \\
\text { Female and male wildtype }\end{array}$ & $\begin{array}{l}(10-21)^{\star} \\
(10-21)^{\star}\end{array}$ & 5-16 weeks & 16 & 1 & $30 \min _{\text {glucose }} \uparrow$ & Not determined \\
\hline \multirow[t]{2}{*}{ Preitner et al. (14) } & $\begin{array}{l}\text { Female GLP-1receptor KO } \\
\text { Female wildtype }\end{array}$ & $\begin{array}{c}6 \\
11\end{array}$ & 3-4 months & 16 & 3 & AUC $_{\text {glucose }} \uparrow \approx 25 \%$ & 15 min $_{\text {insulin }} \downarrow \approx 40 \%$ \\
\hline & $\begin{array}{l}\text { Male GLP-1 receptor KO } \\
\text { Male wildtype }\end{array}$ & $\begin{array}{l}(9-13) \\
(9-13)\end{array}$ & 3-4 months & 16 & 3 & AUC $_{\text {glucose }} \leftrightarrow$ & 15 min $_{\text {insulin }} \leftrightarrow$ \\
\hline \multirow[t]{2}{*}{ Hansotia et al. (14) } & $\begin{array}{l}\text { Female GLP-1 receptor KO } \\
\text { Female wildtype }\end{array}$ & $\begin{array}{l}(4-14)^{*} \\
(4-14)^{*}\end{array}$ & 9-15 weeks & $16-18$ & 1.5 & $\mathrm{AUC}_{\text {glucose }} \leftrightarrow$ & Not determined \\
\hline & $\begin{array}{l}\text { Male GLP-1 receptor KO } \\
\text { Male wildtype }\end{array}$ & $\begin{array}{l}(13-28)^{\star} \\
(4-14)^{\star}\end{array}$ & 9-15 weeks & $16-18$ & 1.5 & $\mathrm{AUC}_{\text {glucose }} \leftrightarrow$ & 10 min $_{\text {insulin }} \leftrightarrow$ \\
\hline
\end{tabular}

*indicates "not reported in individual groups". $\uparrow$ indicates increase, $\downarrow$ reduction and $\leftrightarrow$ no change versus wildtype. 
TABLE 3 | Body weight and baseline glucose and insulin levels and HOMA-R after 5 hrs of fasting in wildtype mice and in GIP receptor KO and GLP-1 receptor KO mice.

\begin{tabular}{lccc}
\hline & Wildtype mice $(\mathbf{n}=\mathbf{9 9})$ & GIP receptor Ko mice $(\mathbf{n}=\mathbf{6 8})$ & GLP-1 receptor KO mice $(\mathbf{n}=\mathbf{7 8})$ \\
\hline Body weight $(\mathrm{g})$ & $21.8 \pm 0.2$ & $22.1 \pm 0.2$ & $20.5 \pm 0.2(\mathrm{P}<0.001)$ \\
Glucose $(\mathrm{mmol} / \mathrm{l})$ & $7.8 \pm 0.1$ & $7.8 \pm 0.1$ & $9.5 \pm 0.1(\mathrm{P}<0.001)$ \\
Insulin $(\mathrm{pmol} /)$ & $231 \pm 9$ & $284 \pm 13(\mathrm{P}=0.069)$ & $226 \pm 13$ \\
Insulin sensitivity (HOMA-R) & $11.6 \pm 0.5$ & $14.3 \pm 0.7(\mathrm{P}=0.020)$ & $14.0 \pm 0.8(\mathrm{P}=0.040)$ \\
\hline
\end{tabular}

Means \pm SEM are shown. P indicates probability level of random difference versus wildtype mice. $n$ indicates number of animals.

\section{Glucose} (mmol/l)

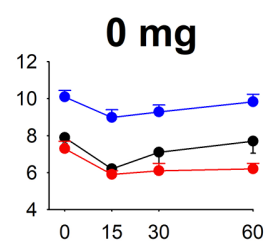

$25 \mathrm{mg}$

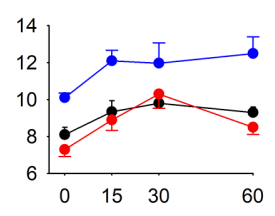

$50 \mathrm{mg}$

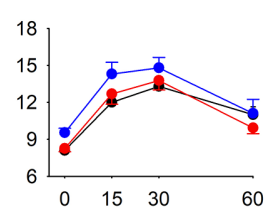

Time (minutes)

\section{Insulin (pmol/l)}

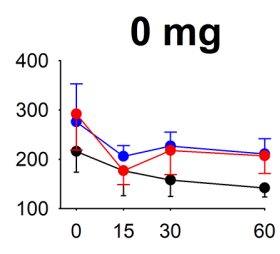

$25 \mathrm{mg}$

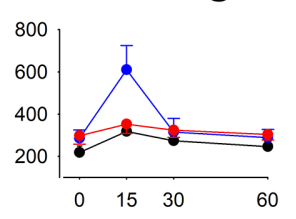

$50 \mathrm{mg}$

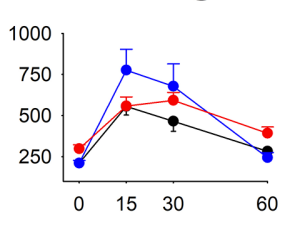

Time (minutes)

\section{Glucose \\ (mmol/l)}

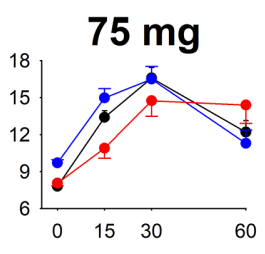

$100 \mathrm{mg}$

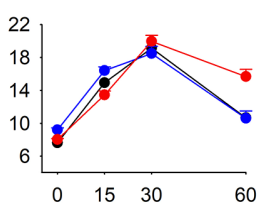

$125 \mathrm{mg}$

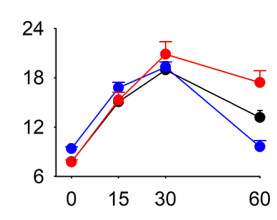

Time (minutes)
Insulin (pmol/l)

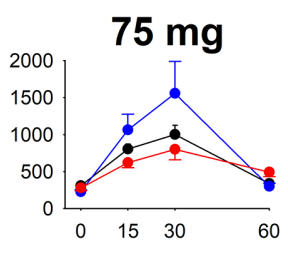

$100 \mathrm{mg}$

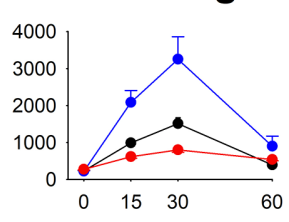

$125 \mathrm{mg}$

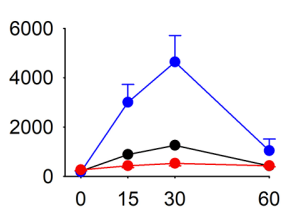

Time (minutes)

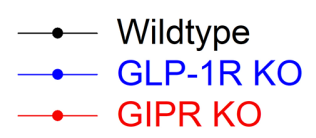

FIGURE 1 | Glucose and insulin levels before and after oral administration of glucose at 0, 25, 50, 75, 100 or 125 mg in wildtype mice, GLP-1 receptor KO mice and GIP receptor KO mice. Means \pm SEM are shown. There were 6-34 animals in each individual group (see Table $\mathbf{1}$ for details). Observe that $y$-axis for the respective panels have been adjusted for the actual levels and are therefore different for the different glucose loads.

there was no further increase in $\mathrm{AUC}_{\text {glucose. }}$ In GIP receptor $\mathrm{KO}$ mice, $\mathrm{AUC}_{\text {glucose }}$ increased by increasing the glucose load with no trend of leveling off at the highest glucose. AUC glucose did not differ in GIP receptor $\mathrm{KO}$ mice from wildtype mice after 25, 50, 75 and $100 \mathrm{mg}$ glucose, whereas AUC $_{\text {glucose }}$ was higher in GIP receptor $\mathrm{KO}$ mice than in wildtype mice after $125 \mathrm{mg}(\mathrm{P}=0.029)$. GLP-1 receptor $\mathrm{KO}$ mice had higher $\mathrm{AUC}_{\text {glucose }}$ than wildtype mice after zero $(\mathrm{P}<0.001)$ and $25 \mathrm{mg}$ glucose administration $(\mathrm{P}=0.007)$, but with no difference at higher glucose doses. Also $\mathrm{AUC}_{\text {insulin }}$ increased gradually in wildtype mice by increasing the gucose load up to $100 \mathrm{mg}$. In GIP receptor $\mathrm{KO}$ mice, $\mathrm{AUC}_{\text {insulin }}$ was significantly lower than in wildtype mice after $100 \mathrm{mg}$ glucose $(\mathrm{P}=0.003)$ and $125 \mathrm{mg}$ glucose $(\mathrm{P}=0.001)$, but not after lower glucose doses. In GLP-1 receptor $\mathrm{KO}$ mice, $\mathrm{AUC}_{\mathrm{insulin}}$ was higher than in wildtype mice after $100 \mathrm{mg}$ glucose and $125 \mathrm{mg}$ glucose (both $\mathrm{P}<0.001$ ) but not at lower glucose doses.

As a marker of the relative increase in $\mathrm{AUC}_{\text {insulin }}$ by increasing the glucose load, the ratio between $\mathrm{AUC}_{\text {insuin }}$ at each of the glucose doses and the $\mathrm{AUC}_{\text {insulin }}$ after zero glucose was calculated (Figure 2). In GIP receptor KO mice, this ratio 

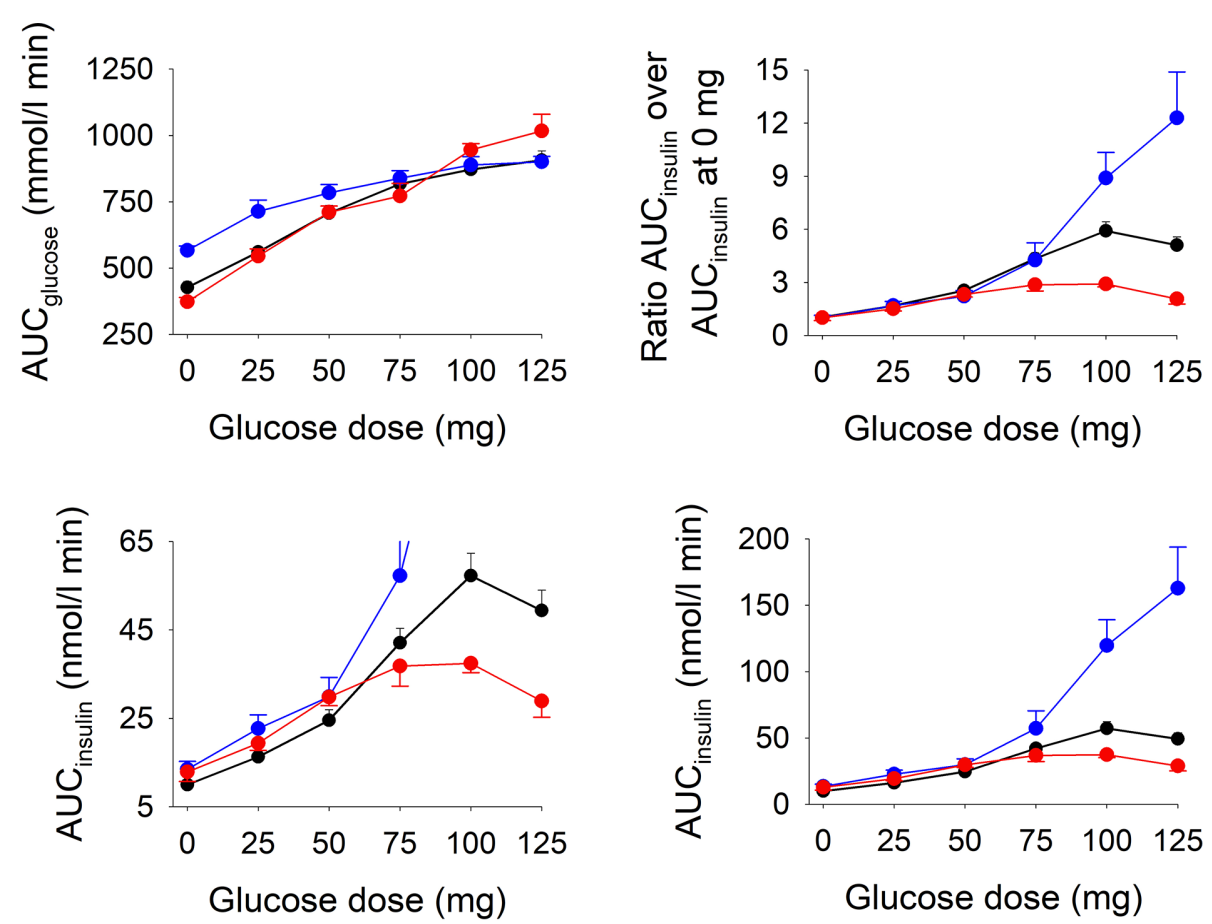

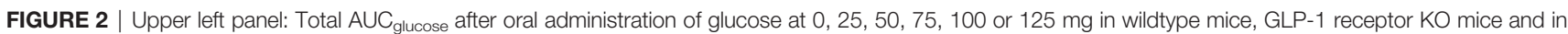
GIP receptor KO mice. Upper right panel: Ratio of total $\mathrm{AUC}_{\text {insulin }}$ after oral administration of glucose at $0,25,50,75,100$ or 125 mg divided by total $A \cup C_{\text {insulin }}$ after saline alone (i.e., zero glucose) in wildtype mice, GLP-1 receptor KO mice and in GIP receptor KO mice. Lower panels: Total AUC glucose at 0, 25, 50, 75, 100 or 125 mg in wildtype mice, GLP-1 receptor KO mice and in GIP receptor KO mice; observe two different ranges in y-axis. Means \pm SEM are shown. There were 6-34 animals in each individual group (see Table $\mathbf{1}$ for details).

was significantly lower than in wildtype mice after $100 \mathrm{mg}$ glucose $(\mathrm{P}=0.007)$ and after $125 \mathrm{mg}(\mathrm{P}=0.008)$. In contrast, the ratios were significantly higher in GLP-1 receptor $\mathrm{KO}$ mice than in wildtype mice after $125 \mathrm{mg}(\mathrm{P}=0.032)$.

As a marker of the beta cell response to oral glucose, $\mathrm{AUC}_{\text {inusulin }}$ was divided by $\mathrm{AUC}_{\text {glucose }}$ at each of the glucose loads (Figure 3). It is seen that this marker was lower in GIP receptor $\mathrm{KO}$ mice than in wildtype mice after $100 \mathrm{mg}(\mathrm{P}=0.036)$ and $125 \mathrm{mg}(\mathrm{P}=0.018)$, and higher in GLP-1 receptor $\mathrm{KO}$ mice than in wildtype mice after $100 \mathrm{mg}(\mathrm{P}=0.029)$ and 125 mg $(\mathrm{P}<0.001)$.

\section{DISCUSSION}

We reviewed the literature on glucose and insulin responses to oral glucose in GIP and GLP-1 receptor KO mice and found that glucose intolerance is not as robustly demonstrated as is generally assumed. In fact, only approximately two thirds of the study arms with GIP receptor or GLP-1 receptor KO mice versus wildtype mice showed glucose intolerance accompanied by a reduced insulin response, whereas in approximately a third of study arms these KO mice had normal glucose tolerance $(8,10-14)$. The explanation may be that the phenotype varies between different KO colonies, but differences in the experimental approaches may also explain the incosistencies. A general limitation of the studies was that they used a long semistarvation fasting period of $>16$ hours and only one single glucose load was used in each study. There was no clear differences in the background data in studies reporting glucose intolerance or normal glucose tolerance in GIP or GLP-1 receptor KO mice, although a trend of a more severe glucose intolerance was reported at higher glucose loads. Thus, studies on glucose tolerance after oral glucose administration in GIP and GLP-1 receptor KO mice show a trend but not a general consistency of glucose intolerance. The trend of differences in results depending on glucose loads prompted the present study of a full-range stepwise glucose administration design in GIP and GLP-1 receptor KO mice.

The stepwise dose-response study evaluated glucose and insulin responses to glucose challenges ranging from 25 to $125 \mathrm{mg}$ in 

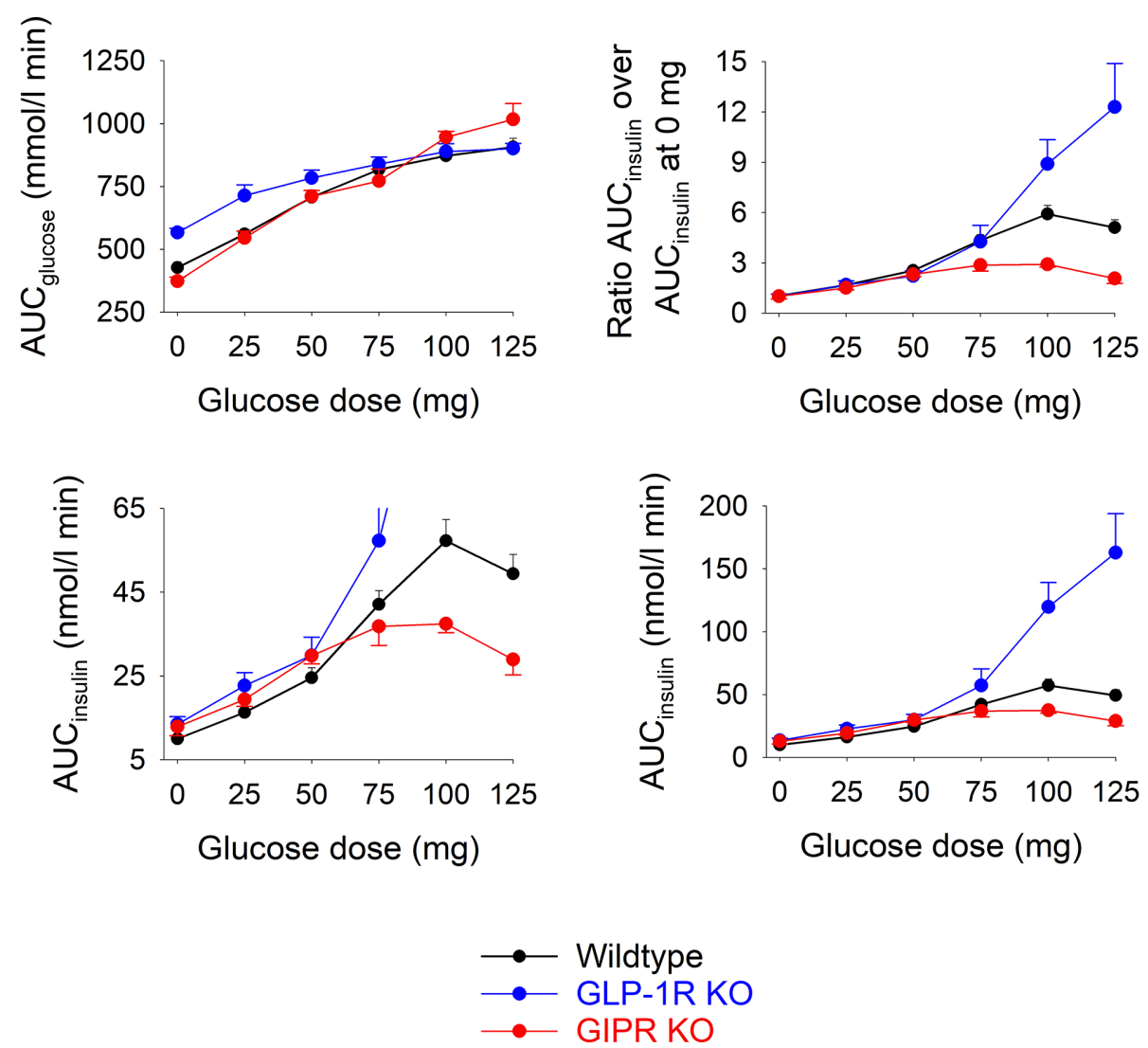

FIGURE 3 | Beta cell response (AUC insulin divided by AUC $_{\text {glucose }}$ ) after oral administration of glucose at 0, 25, 50, 75, 100 or 125 mg in wildtype mice, GLP-1 receptor KO mice and GIP receptor KO mice. Means \pm SEM are shown. There were 6-34 animals in each individual group (see Table $\mathbf{1}$ for details).

wildtype, GIP and GLP-1 receptor $\mathrm{KO}$ mice. Using this large range of glucose allows conclusions after both low and high glucose. Other strengths of the study are that we also included a group with zero glucose administration and that we used mice with a physiological fasting period of five hours, which is in the range of previously reported optimal period for mice in studies on glucose tolerance (18). We also standardized the mice in age of the animals and all experimental studies were performed at the same time of the day and by the same experienced technician. We also included wildtype mice together with receptor $\mathrm{KO}$ mice in each batch of study animals, which is important considering the day-to-day variations in metabolism.

We found that in wildtype mice, glucose levels increased by increasing the glucose load up to the $75 \mathrm{mg}$ dose, thereafter no further increase in glucose levels occur in spite of larger glucose loads. At the same time, insulin levels also increased by increasing the oral gucose load up to $75 \mathrm{mg}$. This together suggests that there is a saturation of glycemia after oral glucose in normal physology in mice and that this is achieved by increasing insulin levels. This has previously been shown also in humans (4) and is ascribed to increased insulin due to glucose in combination with the incretin effect.
The GIP receptor $\mathrm{KO}$ mice had normal glucose tolerance compared to wildtype mice after 25 and $50 \mathrm{mg}$. In contrast, the GLP-1 receptor $\mathrm{KO}$ mice had higher $\mathrm{AUC}_{\text {glucose }}$ than the other groups after 25 and $50 \mathrm{mg}$, but this was mainly related to the higher fasting glucose, which most likely is a phenomenon explained by exaggerated hepatic glucose production due to absence of GLP-1 action to inhibit liver glucose production, which has been demonstrated in rodents (19) and humans (20, 21) and which may be mediated by insulin and glucagon, but also mediated by GLP-1 receptors located in the portal system $(22,23)$. Nevertheless, the increase in glucose levels after oral glucose was similar in GLP-1 receptor KO mice as in the other groups, but from a higher levels. These data together suggest that GLP-1 receptor and GIP receptor $\mathrm{KO}$ mice maintain glucose tolerance after low glucose loads, which supports the trend in the literature that glucose intolerance is rather seen after high glucose loads than after low glucose loads in GIP or GLP-1 receptor KO mice (Table 2).

When glucose loads were raised to 100 and $125 \mathrm{mg}$, glucose levels continued to increase in GIP receptor $\mathrm{KO}$ mice in comparison to lower glucose loads, whereas this was not observed in GLP-1 receptor $\mathrm{KO}$ mice. This is similar as our 
previous results in DIRKO mice, which have both GIP and GLP1 receptor gene deletion (15), whichs suggests that GIP rather than GLP-1 explains the glucose intolerance after high oral glucose loads in DIRKO mice.

The reason why GIP receptor $\mathrm{KO}$ mice had glucose intolerance at higher glucose levels seems to be explained by the failure to further increase insulin levels; in fact, at the high glucose load $\mathrm{AUC}_{\text {insulin }}$ was increased only approximately twofold in GIP receptor $\mathrm{KO}$ mice compared to zero glucose administration, whereas it was increased six times in wildtype mice. In contrast, GLP-1 receptor KO mice had an increase in the insulin response to oral glucose at the high glucose loads of 100 and $125 \mathrm{mg}$. In fact, $\mathrm{AUC}_{\text {insulin }}$ increased more than twelve-fold at $125 \mathrm{mg}$ versus zero glucose compared to six-fold in wildtype mice; this high insulin is most likely the reason that glucose levels were prevented from being increased further. The nature of this compensatory mechanism in GLP-1 receptor KO mice at high oral glucose load is not known but deserves further studies candidates may be the higher baseline glucose levels or compensatory increase in other gut hormones which may mask the consequence of GLP-1 receptor gene deletion. Studies on these adaptive mechanisms are important future development of the present study, since the mechanisms may involve important novel regulatory mechanisms for islet function and glucose tolerance. This may be of relevance also for human physiology and pathophysiology of type 2 diabetes.

Although not within the aim of this study, beta cell function may be indirectly determined by comparing the increase in $\mathrm{AUC}_{\text {insulin }}$ after each of the glucose loads to $\mathrm{AUC}_{\text {insulin }}$ after zero glucose. This was six times higher at $100 \mathrm{mg}$ glucose than at zero glucose in wildtype mice, significantly reduced in GIP receptor $\mathrm{KO}$ mice and enhanced in GLP-1 receptor KO mice. Beta cell activity was also indirectly determined by dividing the increase in insulin levels by the increase in glucose levels at $30 \mathrm{~min}$ after glucose administration. It was found that this marker of beta cell function increased by increasing the glucose load in wildtype mice up to $100 \mathrm{mg}$. In GIP receptor KO mice, beta cell failure was evident after 100 and $125 \mathrm{mg}$ glucose, whereas an adaptive increase in beta cell function was seen in GLP-1 receptor KO mice.

Although the studies have several strengths, of which the use of a full-range stepwise glucose administration design is most important, there are also several limitations with these studies. First, GIP receptor and GLP-1 receptor deletion may result in adaptive responses, which may prevent conclusions on the individual contributions by GIP and GLP-1, and the increase in the insulin response to oral glucose in GLP-1 receptor KO mice is such an adaptation. Further studies using specific pharmacological blockade are therefore warranted. Second, we studied only female mice, and therefore our conclusions are valid only for this gender. Third, we did not determine other potential incretin hormones or glucagon in this study; glucagon secretion in GIP and GLP-1 receptor $\mathrm{KO}$ mice has been examined in previous studies (16).

In conclusion, we have performed a literature survey of studies reporting glucose and insulin levels after oral glucose in
GIP receptor or GLP-1 receptor KO mice and found that glucose intolerance is evident in approximately two thirds of study arms, whereas normal glucose tolerance is evident in one third of study arms. We have also performed a complete dose study by delivering glucose loads from zero to $125 \mathrm{mg}$ to female wildtype and GIP receptor KO and GLP-1 receptor KO mice. We have demonstrated 1) that glucose levels saturate at levels above $75 \mathrm{mg}$ in wildtype mice due to increase in insulin levels, 2) that GIP receptor $\mathrm{KO}$ mice have glucose intolerance after high glucose load due to insufficient increase in insulin levels, and 3) that GLP-1 receptor $\mathrm{KO}$ mice maintain glucose tolerance in spire of having GLP-1 receptor gene deletion due to a compensatory increase in insulin levels.

\section{DATA AVAILABILITY STATEMENT}

The raw data supporting the conclusions of this article will be made available by the authors, upon reasonable request.

\section{ETHICS STATEMENT}

The animal study was reviewed and approved by Lund/Malmö Animal Ethics Committee (Approval No. 5.8.18-06417/2020).

\section{AUTHOR CONTRIBUTIONS}

BA: Conceptualization, Data curation, Formal analysis, Funding acquisition, Investigation, Methodology, Project administration, Resources, Software, Supervision, Validation, Writing - original draft, Writing - review \& editing. YY: Writing - review and editing. YS: Writing - review and editing. All authors contributed to the article and approved the submitted version.

\section{FUNDING}

This research was funded by the Lund University Medical Faculty, Region Skåne, and the Swedish Research Council (to B. Ahrén).

\section{ACKNOWLEDGMENTS}

We acknowledge Tina Ovlund of Lund University for expert technical assistance and Dr. Daniel J. Drucker of the LunenfeldTanenbaum Research Institute of Mount Sinai Hospital, Toronto, ON, Canada, for provision of the GLP-1 receptor KO mice used in the creation of the mouse strains used in these studies for producing the mice. 


\section{REFERENCES}

1. Jagannathan R, Neves JS, Dorcely B, Chung ST, Tamura K, Rhee M, et al. The Oral Glucose Tolerance Test: 100 Years Later. Diabetes Metab Syndr Obes (2020) 13:3787-805. doi: 10.2147/DMSO.S246062

2. Deacon CF, Ahrén B. Physiology of Incretins in Health and Disease. Rev Diabetic Stud (2011) 7:293-306. doi: 10.1900/RDS.2011.8.293

3. Campbell JE, Drucker DJ. Pharmacology, Physiology, and Mechanism of Incretin Hormone Action. Cell Metab (2013) 17:819-37. doi: 10.1016/ j.cmet.2013.04.008

4. Holst JJ. The Incretin System in Healthy Humans: The Role of GIP and GLP1. Metabolism (2019) 96:46-55. doi: 10.1016/j.metabol.2019.04.014

5. Nauck MA, Homberger E, Siegel EG, Allen RC, Eaton RP, Ebert R, et al. Incretin Effects of Increasing Glucose Loads in Man Calculated From Venous Insulin and C-peptide Responses. J Clin Endocrinol Metab (1986) 63:492-8. doi: 10.1210/jcem-63-2-492

6. Ahrén B, Winzell MS, Pacini G. The Augmenting Effect on Insulin Secretion by Oral Versus Intravenous Glucose is Exaggerated by High-Fat Diet in Mice. J Endocrinol (2008) 197:181-7. doi: 10.1677/JOE-07-0460

7. Hansotia T, Drucker DJ. GIP and GLP-1 as Incretin Hormones: Lessons From Single and Double Incretin Receptor Knockout Mice. Regul Pept (2005) 128:125-34. doi: 10.1016/j.regpep.2004.07.019

8. Scrocchi LA, Brown TJ, MaClusky N, Brubaker PL, Auerbach AB, Joyner AL, et al. Glucose Intolerance But Normal Satiety in Mice With a Null Mutation in the Glucagon-Like Peptide 1 Receptor Gene. Nat Med (1996) 2:1254-8. doi: 10.1038/nm1196-1254

9. Scrocchi LA, Marshall BA, Cook SM, Brubaker PL, Drucker DJ. Identification of Glucagon-Like Peptide 1 (GLP-1) Actions Essential for Glucose Homeostasis in Mice With Disruption of GLP-1 Receptor Signaling. Diabetes (1998) 47:632-9. doi: 10.2337/diabetes.47.4.632

10. Pederson RA, Satkunarajah M, McIntosh CHS, Scrocchi LA, Flamez D, Schuit F, et al. Enhanced Glucose-Dependent Insulinotropic Polypeptide Secretion and Insulinotropic Action in Glucagonlike Peptide 1 Receptor -/- Mice. Diabetes (1998) 47:1046-52. doi: 10.2337/diabetes.47.7.1046

11. Miyawaki K, Yamada Y, Yano H, Niwa H, Ban N, Ihara Y, et al. Glucose Intolerance Caused by a Defect in the Entero-Insular Axis: A Study in Gastric Inhibitory Polypeptide Receptor Knockout Mice. Proc Natl Acad Sci USA (1999) 96:14843-7. doi: 10.1073/pnas.96.26.14843

12. Pamir N, Lynn FC, Buchan AM, Ehses J, Hinke SA, Pospisilik JA, et al. Glucose-Dependent Insulinotropic Polypeptide Receptor Null Mice Exhibit Compensatory Changes in the Enteroinsular Axis. Am J Physiol Endocrinol Metab (2003) 284:E931-9. doi: 10.1152/ajpendo.00270.2002

13. Preitner F, Ibberson M, Franklin I, Binnert C, Pende M, Gijnovci A, et al. Gluco-Incretins Control Insulin Secretion At Multiple Levels as Revealed in Mice Lacking GLP-1 and GIP Receptors. J Clin Invest (2004) 113:635-45. doi: 10.1172/JCI200420518
14. Hansotia T, Baggio LL, Delmeire D, Hinke SA, Yamada Y, Tsukiyama K, et al. Double Incretin Receptor Knockout (DIRKO) Mice Reveal an Essential Role for the Enteroinsular Axis in Transducing the Glucoregulatory Actions of DPP-IV Inhibitors. Diabetes (2004) 53:1326-35. doi: 10.2337/diabetes.53.5.1326

15. Ahrén B, Yamada Y, Seino Y. The Incretin Effect in Female Mice With Double Deletion of GLP-1 and GIP Receptors. J Endocr Soc (2019) 4:bvz036. doi: 10.1210/jendso/bvz036

16. Tura A, Pacini G, Yamada Y, Seino Y, Ahrén B. Glucagon and Insulin Secretion, Insulin Clearance, and Fasting Glucose in GIP Receptor and GLP-1 Receptor Knockout Mice. Am J Physiol Regul Integr Compar Physiol (2019) 316:R27-37. doi: 10.1152/ajpregu.00288.2018

17. Pacini G, Omar G, Ahrén B. Methods and Models for Metabolic Assessment in Mice. J Diabetes Res (2013) 2013:986906. doi: 10.1155/2013/986906

18. Andrikopoulos S, Blair AR, Deluca N, Fam BC, Proietto J. Evaluating the Glucose Tolerance Test in Mice. Am J Physiol Endocrinol Metab (2008) 295: E1323-1332. doi: 10.1152/ajpendo.90617.2008

19. Van Dijk G, Lindskog S, Holst JJ, Steffens AB, Ahrén B. Effects of GlucagonLike Peptide 1 on Glucose Turnover in Rats. Am J Physiol (1996) 270:E101521. doi: 10.1152/ajpendo.1996.270.6.E1015

20. Hvidberg A, Toft-Nielsen M, Hilsted J, Ørskov C, Holst JJ. Effect of GlucagonLike Peptide-1 (Proglucagon 78-107 Amide) on Hepatic Glucose Production in Healthy Man. Metabolism (1994) 43:104-8. doi: 10.1016/0026-0495(94) 90164-3

21. Larsson H, Holst JJ, Ahrén B. Glucagon-Like Peptide-1 Reduces Hepatic Glucose Production Indirectly Through Insulin and Glucagon in Humans. Acta Physiol Scand (1997) 160:413-22. doi: 10.1046/j.1365-201X.1997.00161.x

22. Vahl TP, Tauchi M, Durler TS, Eifer EE, Fernandes TM, Bitner RD, et al. Glucagon-Like Peptide-1 (GLP-1) Receptors Expressed on Nerve Terminals in the Portal Vein Mediate the Effects of Endogenous GLP-1 on Glucose Tolerance in Rats. Endocrinology (2007) 148:4965-73. doi: 10.1210/en.20060153

23. Malbert CH. Chauvin A, Horowitz M, Jones KL. Glucose Sensing Mediated by Portal Glucagon-Like Peptide 1 Receptor is Markedly Impaired in InsulinResistant Obese Animals. Diabetes (2021) 70:99-110. doi: 10.2337/db20-0361

Conflict of Interest: The authors declare that the research was conducted in the absence of any commercial or financial relationships that could be construed as a potential conflict of interest.

Copyright (c) 2021 Ahrén, Yamada and Seino. This is an open-access article distributed under the terms of the Creative Commons Attribution License (CC BY). The use, distribution or reproduction in other forums is permitted, provided the original author(s) and the copyright owner(s) are credited and that the original publication in this journal is cited, in accordance with accepted academic practice. No use, distribution or reproduction is permitted which does not comply with these terms. 